\title{
PROBLEMS OF LINGUISTIC STUDIES OF PROFESSIONAL LANGUAGE IN UKRAINE
}

\author{
Mamich M. V., Shevchenko-Bitenska O. V.
}

\section{INTRODUCTION}

During the last two decades it has being actively worked on the development of the course "Ukrainian language for professional purposes", "Ukrainian language of professional communication" in Ukraine. Attention to this theoretical and practical direction is due to a significant expansion of the Ukrainian language spheres, primarily - the introduction of the Ukrainian literary language in specialized education.

The problem "Ukrainian language as an educational subject in professional microsocieties "and" Ukrainian language as a means of activity in professional groups" are processed in varying degrees. This is evidenced by both scientific publications and numerous textbooks. In our opinion, there are some difficulties in the formation of special educational courses on the Ukrainian language as a professional language arise due to insufficient: understanding the phenomenon of "professional language", the study of the specialized sublanguages, the development of linguodidactic principles of teaching the Ukrainian language as a language of specialization.

In the offered fragment the questions of history of studying of professional language in Ukraine, theoretical preconditions of separation of language of special purpose are comprehended, problems of researches in the corresponding segment of knowledge about the Ukrainian literary language are offered.

\section{From the history of learning professional language (until the 90s of the twentieth century)}

Social factors. The history of this issue dates back centuries, when special courses and lectures were created at workers' faculties, and later at higher educational institutions. In the first decade of October, with the help of Ukrainian language scientific literature began to be created actively, as well as dictionaries of terms were formed. After the formation of the Ukrainian People's Republic in March 1917, the first Ukrainian gymnasium was opened in Kyiv, and in 1918 the law of the Ukrainian People's Republic on the state status of the Ukrainian language was approved (February 15, 1918). At the Ministry of Education, the spelling commission was headed by I. Ogienko. On May 24, 1918, the "Main Rules of Ukrainian Spelling" were 
approved, and in 1924 the Institute of Scientific Language was established at the Ukrainian Academy of Sciences. In 1921-1933 there were attempts to Ukrainianize science and public administration in Soviet Ukraine. The issue of forming the Ukrainian language environment has become relevant.

The development of linguodidactics (level principle of language learning). Against the background of these processes, scientists, teachers of Kharkiv universities - L.A. Bulakhovsky, B.O. Tkachenko and others work out special courses, which highlight the issue of the status of special terminological vocabulary as the basis of scientific style, business language, and more broadly - professional training.

As noted by T.Y. Lysychenko, "Perhaps the greatest contribution to this work was made by L.A. Bulakhovsky, who owned the largest section "Grammar", as well as stylistic aspects. The structure of the Ukrainian language course developed by Kharkiv scholars (O.I. Biletsky, O. Paradizky, M.F. Sulima joined them) has been preserved up to nowadays. This manual has survived several editions and to some extent became the basis of other textbooks on the Ukrainian language. ${ }^{1}$

During the investigation of the Kharkiv philological school development, O.S. Cheremska noted that during this period "L. Bulakhovsky's textbook on the Ukrainian language for labor schools was known. V, VI, VII years of study (co-authored with O.I. Biletsky and other authors; published in two editions - in 1927 and 1928). ${ }^{2}$ Separate textbooks - "Advanced course of the Ukrainian language. Lectures" (Kharkov, 1929); "General course of the Ukrainian language. Lectures" (Kharkiv, 1929-1930); "Ukrainian language course for employees. Lectures" (Kharkiv, 1930) - edited by L.A. Bulakhovsky.

In the following decades this issue was not worked with, it was not cared about the formation of specific principles of linguodidactic in the professional sphere as social functions of Ukrainian language were narrowed.

The development of specialized referential literature. Another indicative principle of linguodidactics in the spheres of scientific and scientifictechnical activity is lexicographic principle.

During the period 10-30's of the twentieth century dozens of textbooks on the Ukrainian literary language were published: 13 textbooks were published in 1919-1924, and more than 60 textbooks in the following years

1 Лисиченко Т.Ю. Леонід Арсенійович Булаховський (до 125-річчя від дня народження). Лінгвістичні дослідження. 2013. Випуск 35. С. 277.

2 Черемська О.С. Становлення і розвиток Харківської філологічної школи (XIX - перша третина XX ст.). Харків : Видавець Савчук О.О. 2020. С. 110. 
(until 1933). A large number of dictionaries on legal language and administrative terminology (according to the bibliography of L. Chervinska and A. Dyky) ${ }^{3}$. In particular, E. Vanko's dictionaries "Pocket RussianUkrainian legal dictionary for lawyers, notaries and government officials" (K., 1918); "Short Moscow-Ukrainian Dictionary of Judiciary and Record Keeping" (Poltava, 1918); V. Leontovych, O. Yefimova "MoscowUkrainian Law Dictionary" (K., 1919); M. Osipova "Russian-Ukrainian dictionary of the most necessary words in office work (practical guide)" (Kharkov, 1926); "Russian-Ukrainian Dictionary of Legal Language", ed. A.Y. Krymsky (K., 1926), "Russian-Ukrainian Dictionary of Business Language" by E. Pluzhnyk and V. Pidmohylny (1926) and others.

In the 80's the most popular publications in the field of official communication were the works of A.P. Koval that is known nowadays, as well as A.S. Golovach "Registration of documents" (70-90's of the twentieth century.).

Attention to structural-functional and socio-cultural differentiation of literary language. Relying on the little-known work of B.D. Tkachenko "Essay on Ukrainian stylistic", O.S. Cheremska stressed that in the context of expanding the functions of the Ukrainian literary language, in particular as an educational tool for various socio-cultural groups, the author's thesis is interesting: "Linguistic community is a product of cultural development; this common language is a consciously organized work, extremely complex in all its branches, serving various activities of cultural society (technology, science, art), and placed before each member of the language community, as a categorical norm (the separation is our M.M.) as a final condition and a sign of a certain "high" position in this community". ${ }^{4}$

Thus, the Ukrainian literary language is the same for everyone, but it quite naturally has specific properties in the micro-communities of speakers. The concept of "language of specialists in production" remains relevant in the 60's of the twentieth century. ${ }^{5}$ It was constantly in sight. Because the 2volume "Dictionary of Slavic Linguistic Terminology" (published in the 70 's, but formed on the postwar material) fixed among the concepts that call

\footnotetext{
${ }^{3}$ Червінська Л.Ф., Дикий А.Т. Покажчик української мови : матеріали по 1929 р. Харків, 1929 (1930). 287 с.

4 Черемська О.С. Становлення і розвиток Харківської філологічної школи (XIX - перша третина XX ст.). Харків : Видавець Савчук О.О. 2020. С. 213.

Закономірності розвитку українського усного літературного мовлення / [Баранник Д.Х., Білодід І.К., Близниченко Л.А. та ін.] ; за ред. І.К. Білодіда. Київ : Наукова думка, 1965. С. 305.
} 
a separate style of literary language, the term "professional (special) style". ${ }^{6}$ Accordingly, among the stylistically colored means - means of professional (special) language.

Thus, one of the preliminary conclusions: in the first three decades of the twentieth century the principles of Ukrainian language teaching, in particular in specialized areas of its application, based on the level principle were developed.

The formation of terminology for describing the narrow spheres of Ukrainian literary language functioning. First, it should be talked about the formation of basic terms of the theory of professional communication. To characterize the Ukrainian language in professional environments, the terms "vocabulary of scientific language", "vocabulary of business language", "professional and industrial vocabulary" are used.

The codification of the term "professionalism" also has a history. In the courses of L.A. Bulakhovsky's respective groups of words are called differently, in particular, "industrial and technical vocabulary", "professional and industrial" ". Mostly this concept was very close in its content and interpretation to the concept of "terminological vocabulary". Even in the postwar 50's the courses of modern Ukrainian literary language were formed, which use the concept of "professional production vocabulary" - the names of various tools, phenomena and processes of production, materials. ${ }^{9}$ Researchers continue to use the terms "professional word", "professional vocabulary", "professional-terminological vocabulary" as synonyms in the 60's and 80's.

It is no coincidence that V.S. Vashchenko noted: "The extraction of this group of language units as a part of language is due to both scientific and educational interests that arise in the process of analyzing and refining the characteristics of each word and determining its functional scope"10 In general, this group of vocabulary belongs to the book vocabulary, but each time researchers, building a research platform, emphasize the differentiation

${ }^{6}$ Словарь славянской лингвистической терминологии; под ред. А. Эдлички. Прага, 1977.

${ }^{7}$ Сучасна українська літературна мова : стилістика ; за ред. І.К. Білодіда. Київ : Наукова думка, 1973. С. 88.

${ }^{8}$ Курс сучасної української літературної мови ; за ред. Л.А. Булаховського. Київ : Радянська школа, 1951. Т. 1. С. 41

9 Жовтобрюх, М.А., Кулик Б.М. Курс сучасної української літературної мови : [у 2 ч.]. Київ : Радянська школа, 1965. Ч. 1. С. 72.

10 Ващенко В. С. Українська лексикологія: семантико-стилістична типологія слів. Дніпропетровськ : Вид-во ДДУ, 1979. С. 92-93. 
of professional vocabulary and terms. ${ }^{11}$ In particular, O.Y. Golovanova stressed that specialized vocabulary generally reflects the degrees of human cognition of the material and spiritual world. ${ }^{12}$ Therefore, professionalism, as well as the term, is a verbalizer of special knowledge, but it is created and functions mainly in the field of practice, not theory. The part of industrial information that is actualized in daily actions and operations is fixed in professionalisms, and that's why - through experience - makes the circle of the personal world of a person, its everyday concepts. The researcher believes that for professionalisms it is important not objective (as for the term) and therefore averaged, detached from reality form of the sign, but subjective, associated with the image, game, creativity, or reflecting the practical significance of the subject of professional activity: perceptual characteristics of the object of nomination, its acting properties, etc. ${ }^{13}$

The principles of differentiation of professionalisms and terms are generalized by the following table:

According to some sources, it is observed that professionalisms and communicative professionalisms are differentiated (O.Y. Golovanova). The latter - "the result of phonetic, grammatical, word-formation change of terms, which is associated with their adaptation to the conditions of oral group communication (language economy, reflecting the nature of the relationship between communicators, etc.). Such professionalisms are means of short and capacious exchange of information in the conditions of collective communication (such as: інструменталка - інструментальний цех, роба - робочий одяг, швейка - швацький цеех, шпулька - шпульний ковпачок еtc.)". ${ }^{14}$ In fact, it is professional jargon. Accordingly, words of narrow professional use, depending on the degree of their normativeness, are characterized as professional conversational doublets ( $\mathrm{N}$. Garbovsky, L. Kapanadze), professional slang (K. Levkovskaya). Communicative professionalisms are expressively colored. Professionalisms in the field of craft activities belong to the folk-talkative language, i.e. are on the border of literary and folk national language practice (D.H. Barannik).

11 Михайлова Т.В. Семантичні відношення в українській науково-технічній термінології. Харків, 2001. С. 44-45; Пристайко Т.С. Лексико-номинативная организация специального текста. Дніпропетровськ : УкО IMA-прес, 1996. с. 50; Винник В.О. Професіоналізм. Українська мова. Енциклопедія. Київ, 2004. С. 500.

${ }^{12}$ Голованова Е.И. Введение в когнитивное терминоведение. Москва : Флинта; Наука, 2011. С. 56.

${ }^{13}$ Same p. 98.

${ }^{14}$ Same p. 99. 


\begin{tabular}{|c|c|c|c|}
\hline & $\begin{array}{c}\text { Principles of } \\
\text { differentiation }\end{array}$ & Professionalism & Term \\
\hline 1. & $\begin{array}{l}\text { According to } \\
\text { prevalence in } \\
\text { language practice }\end{array}$ & $\begin{array}{l}\text { Professional / specialized oral } \\
\text { and conversational } \\
\text { environment. } \\
\text { Local abbreviated and } \\
\text { simplified names that } \\
\text { duplicate terms and are } \\
\text { secondary in terms of terms. } \\
\text { Can be included in } \\
\text { terminological subsystems. } \\
\text { May be inherent in individual } \\
\text { language practice. }\end{array}$ & $\begin{array}{l}\text { The language of science } \\
\text { is oral and written. } \\
\text { Cannot have a narrow } \\
\text { local character. } \\
\text { Function in all spheres } \\
\text { of scientific and } \\
\text { industrial activity of the } \\
\text { person. }\end{array}$ \\
\hline 2. & $\begin{array}{l}\text { According to official } \\
\text { recognition, } \\
\text { codification }\end{array}$ & Semi-official & Normalized \\
\hline 3. & $\begin{array}{l}\text { According to the } \\
\text { presence of a } \\
\text { connotative } \\
\text { component }\end{array}$ & $\begin{array}{l}\text { Inherent connotations } \\
\text { (expressive coloring) }\end{array}$ & $\begin{array}{l}\text { Should not have an } \\
\text { emotionally expressive } \\
\text { coloring }\end{array}$ \\
\hline 4. & Ways of creation & $\begin{array}{l}\text { On the basis of the national } \\
\text { language, only in some units } \\
\text { there are foreign language } \\
\text { elements }\end{array}$ & $\begin{array}{l}\text { By means of the national } \\
\text { and foreign languages }\end{array}$ \\
\hline 5. & $\begin{array}{l}\text { Systemacity } \\
\text { connections } \\
\text { (paradigmatics) }\end{array}$ & Weak & Expressive \\
\hline 6. & $\begin{array}{l}\text { Features of } \\
\text { semantics }\end{array}$ & $\begin{array}{l}\text { Do not correlate a } \\
\text { phenomenon with its } \\
\text { definition, but compare it } \\
\text { with other phenomena on the } \\
\text { basis of some, one, not even } \\
\text { the main, external sign of } \\
\text { similarity. } \\
\text { Formed by metonymization } \\
\text { and metaphorization; } \\
\text { ambiguity of semantics } \\
\text { depending on the } \\
\text { environment of application. } \\
\text { According to semantic } \\
\text { groups scientific-technical, } \\
\text { professional-industrial, craft. }\end{array}$ & $\begin{array}{l}\text { Співвіднесений з } \\
\text { поняттям, емоційно } \\
\text { нейтральний, } \\
\text { однозначність, } \\
\text { точність семантики. } \\
\text { Шляхи творення - } \\
\text { переосмислення } \\
\text { загальновживаної чи } \\
\text { професійно обмеженої } \\
\text { лексики, перенесення } \\
\text { термінів із однієї галузі } \\
\text { в іншу, калькування, } \\
\text { використання } \\
\text { словосполучень, } \\
\text { спеціалізація } \\
\text { формантів у структурі } \\
\text { терміну (семантичний, } \\
\text { словотвірний, } \\
\text { синтаксичний шляхи } \\
\text { творення). }\end{array}$ \\
\hline
\end{tabular}


Actually, professionalisms are divided according to the degree of distribution into (1) general scientific / general technical - common in several spheres of professional activity; (2) industry; (3) highly specialized. ${ }^{15}$

Secondly, in parallel, the historical aspect of the formation of the discipline "Ukrainian language for professional purposes" requires consideration of a broader problem - the formation of official business language as the basis of professional language. Interest in this aspect in recent years has contributed to the emergence of a number of dissertations and monograph.

Some studies present the historical aspects of the formation of official business practice in the first decades of the twentieth century. (L. Tymenko, O. Tikhonenko, O. Boyarchuk, I. Farion, N. Dzyubyshyna-Melnyk, O. Sushko). They are characterized by the following central theoretical and practical issues: the status of official business nomenclature, industry terminological systems (at the lexical, lexical-syntactic, lexical-grammatical levels). In fact, in the 20s and following years from the beginning of the twentieth century the literary nature of the Ukrainian literary language became more pronounced, which began to function in the sphere of teaching workers, engineers, financial and economic, legal, and other professions. Active lexical and phraseological processes in the Ukrainian literary language of the first decades of the twentieth century influenced the archaization of some components, the removal of dialectisms from the business environment, the expansion of the vocabulary of the business language borrowed from Latin, German, French and Italian, the renewal of the vocabulary of trade and industry, legal, financial, diplomatic spheres. Word-forming processes were accompanied by the expansion of variability, the coexistence of "old and new".

Researchers, in particular, recorded the following main thematic groups of business language vocabulary: a) names of state organizations, institutions and non-governmental organizations: ministry, party, club, school, church, office, bank, bureau, house, gymnasium, institute, administration, government, etc.; b) names of persons holding positions: president, minister, mayor, director, manager; c) names of documents, securities: act, application, protocol, receipt, certificate, letter, act paper, promissory note, decree, patent, statement, spear, etc.; d) designation of obligatory elements of the document and possible actions of officials: agenda, to approve, to the order, to solve, to give instructions, to undertake. ${ }^{16}$

15 Канделаки Т.Л. Значение терминов и системы значений научно-технических терминологий. Проблемы языка науки и техники: логичиские, лингвистичиские и историко-научные аспекты терминологии. Москва, 1970. 232 с.

16 Тихоненко О.В. Становлення норм офіційно-ділового стилю української мови у 20-30-ті рр. ХХ ст. : автореф. дис. ... канд. філол. наук. Харків, 2011. С. 125. 
Cancellerisms, which entered the official business circulation of all levels of business communication in the first decades of the twentieth century are also demonstrative. They were recorded in dictionaries that became a support for clerks, namely words and expressions of limited use: to inform, mentioned above, to declare, a trustee, named, mentioned below, given above, named above, signed below, and so on. ${ }^{17}$

The elaboration of the sources of business language of the last years as tokens of official communication expands the source base of studying the professional environment.

Sources of research of the language of the professional environment. Since the first decades of the twentieth century, when the vulgar-sociological approach to the evaluation of the language of fiction still prevailed, there were relevant works that assessed the "modernity" of the language of the work in terms of accuracy and truthfulness of its reflection, in particular at the lexical level - according to its functions, terms, vocabulary of special use.

Note that there is still a tendency to study the language of professional micro-societies by artistic sources (we will name among the latest studies on the language of Ivan Franko, I. Tsikhotsky, L. Bagnyuk, which highlights the aspect of special vocabulary; J. Krasnozhan, M. Vus, and others studied the issue of determinologization of a special lexicon in literary texts. Another source is the language of journalism and the media. Such studies were especially relevant in the 70-80's of the twentieth century.

In this regard, it should be noted that in Ukraine it was prepared a number of studies, the object of which is the language of a particular profession, field of knowledge or activity, which will serve to create special courses on teaching the Ukrainian language in a professional field. Here are just a few examples of dissertations and relevant publications on the terminological subsystems of modern Ukrainian literary language: library and bibliographic (M. Stashko), construction (V. Marchenko), veterinary (M. Dmitruk), publishing (M. Protsyk), geological (M. Fed), hydromeliorative (L. Malevich), as well as mining, homeopathic, graphic design, documentation, environmental, economic, electrical, forensic, marketing, medical, metallurgical, mineralogical, musical, scientific and technical, fine arts, pedagogical, legal, sports, chemical, law; artistic ceramics; artistic wood carving; automotive, public administration, journalism, land management and cadastre, computer science, cosmetics and cosmetology, mechanical engineering, oil and gas industry, taxation, programming, etc.

Attention to all these sources is the way to update the methods and methodology of courses "Ukrainian language for professional purposes".

${ }^{17}$ The same. 


\section{Ukrainian language of professional orientation - an academic discipline of the late $X X$ - early XXI centuries}

The change of socio-political factors in the early 90's again brought attention to the Ukrainian language as a way of teaching the profession, training of future generations.

To meet the broad needs of society in the new editions of official communication develop the structure of Ukrainian language courses, substantiate a number of basic concepts of professional oral and written communication. ${ }^{18}$ In contrast to the previous period, in the linguistic literature, together with the actualized terms "business language", "official business language practice", "language of office", the concepts of "professional language", "language for special purposes", "special background", "special language", "sublanguage", etc., and finally the abbreviation LSP (language for specific purposes) became widespread. As it is known, the term was introduced for linguistic didactic purposes in the work "English for Specific Purposes: A Learning-Centered Approach", authored by T. Hutchinson and A. Waters, 1987), sociolinguistic terms "subtext" (known since 60's of the twentieth century) ${ }^{19}$, "sublanguage", "sociolect", "special purpose language" (L.V. Turovskaya), "language for special needs" (I.M. Plotnitskaya, O.P. Levchenko, Z.F. Kudryavtseva)). Even their narrower analogues - the language of science, business language - are still used in Ukrainian linguistics as synonyms for the corresponding terms to denote the functional and stylistic varieties of literary language, for example: scientific style, official business style. According to paradigmatic correlations, the term LSP is related to the concept of LGP 'common language'. Against the background of the latter, special purpose language is a formed subsystem of means of reflecting special knowledge about human activities and the nature of things, which is formed in the corporate language environment. ${ }^{20}$

First of all, the interpretation of the basic concept of "(Ukrainian) language of professional orientation" or "professional language" in numerous textbooks attracts attention. It is mostly understood as:

${ }^{18}$ Мамич М.В. Ділова українська мова в публічному управлінні : навчальний посібник. Одеса. 2020. 68 с.

19 Раздуев А.В. Современный английский подъязык нанотехнологий: структурно-семантическая, когнитивно-фреймовая и лексикографическая модели: дис. ... кандидата филологических наук. Пятигорск, 2013. С. 39.

20 Лейчик В. М. Языки для специальных целей - функциональные разновидности современных развитых национальных языков. Общие и частные проблемы функииональных иелей. Москва : Наука, 1986. с. 28-43; Забросаева И.А., Конурбаев М.Э. От LSP до специализированного дискурса: исторический срез. Язык, сознание, коммуникация: Сб. статей ; ред. В.В. Красных, А.И. Изотов. Москва : МАКС Пресс, 2014. Вып. 49. 
- normalized discipline, which studies the structural features of modern Ukrainian literary language in order to further their application in professional activities (engineer, lawyer, physician, accountant, etc.);

- functional variety of Ukrainian literary language, which is used by representatives of a certain industry, profession, occupation;

- subsystem of modern literary language, which is used mainly by representatives of a certain profession.

In our opinion, not everything is unambiguous in this interpretation (the same assumptions are expressed by other researchers, in particular, it is well systematized in the work of T.N. Khomutova). ${ }^{21}$

There is a double interpretation of "professional language" as a subject and as a separate sublanguage, characterized by the same phonetic and grammatical norms that are inherent in literary language, but with a specific lexical and phraseological array, developed in particular in oral communication. These two values are objectively determined.

What is seen as inaccuracies in the identification of "language of professional communication" and "subtext"? Literary, national language is an integrity that is stratified depending on the functional scope, communicative and pragmatic tasks. It will be recalled that in common usage "subtext" involves a certain range of thematically and genre-related texts (subtext of navigation, subtext of journalism, oral / written language), it is a mini-system, which provides, in addition, coverage of a certain social group of people; it has a pronounced functional and stylistic orientation (for example, the subtext of navigation to the scientific style; the subtext of journalism - to the journalistic style, etc.). That is, the "subtext" is the primary link of a certain communicative environment. The subject-thematic sphere determines the conditional structuring of the integral national language practice.

Thus, common in the "language of professional communication" and "subtext" is the thematic subject spheres in a conditionally homogeneous system.

Another correlation is "language of professional communication" and "functional style". The latter is a kind of literary language in one or another socially important sphere of activity with characteristic functions and norms of communication. Unlike the language of the individual, it is a socially conscious activity. In the Ukrainian literary language it is not customary to distinguish production style, technical style, etc., but to distinguish six or seven the most important segments of language and cultural activities, in particular: conversational and every day, where language is a means of serving family, friends and other relationships; artistic with the function of aesthetic

${ }^{21}$ Хомутова Т.Н. Язык для специальных целей (LSP): лингвистический аспект. Вестник ЮУрГУ. 2007. № 16. С. 70. 
reflection of reality and the formation of social consciousness; journalistic, which creates and broadcasts socially important information, forms public moods, relationships, etc.; church-religious, which supports faith in God, transmits the moral values of existence; scientific with the function of creating and transmitting systematized knowledge about the world and man in it; official and business with a complex system of state-building, legislative, regulatory functions, maintenance of public order, organization of production teams, relations between the state and its citizens, etc.

At the heart of the differentiation of styles is the purpose of communication, the nature of everyday life, social and industrial relations. They are intertwined in real life, and therefore there are many transitional genre-style varieties of language, backgrounds. For all styles there is a joint common literary area that covers the lexical and grammatical arsenal of national literary practice. At the same time, there are atypical for other spheres of linguistic and cultural activity means (stylistic linguistic means), which provide differentiation of language functions. Thus, the functional style is not limited by subject areas. It enables mutual understanding of specialists in certain segments of public language practice. "Functional style" is a concept broader than the concept of "language of professional communication".

Another correlation is "language of professional communication" and "register" of language. In stylistics, emotionally evaluative, expressive registers are known, in particular, expressive backgrounds - formality, affection, intimacy, bookishness, etc. These are situational types of communication that are related to the main styles of language and have characteristic lexical-word-forming, lexical-semantic, lexical-grammatical markers and their configurations. The register of communication bears the imprint of individual language habits, in contrast to public in the field of professional relations.

If we finally correlate the "language of professional communication" with the features of other communicative subsystems of national or globalized language practice, we will see that the professional language:

- has a subject area in a particular social segment of social practice;

- is based on an official, semi-official register of communication;

- its lexical and grammatical content is correlated with the concepts of a certain sphere of human activity;

- its textual and genre expression is relevant to the inherent functions and social roles of speakers.

Thus, the assertion that "professional language" is a functional variety of literary language is debatable. After all, the latter belong to the styles of language, not to sublanguage. The fact that "professional language" is a communicative subsystem is the most optimal explanation. It should be taken as a basis in the theoretical and practical presentation of special courses in professional language. 
"Professional language" ("language of profession") is a language tool at all levels, which are used in specialized areas of activity in order to ensure professional understanding between participants in the field of social activities.

In fact, the scientific and technical environment itself is one of the first socio-cultural segments of the language of special use, or rather lexical and grammatical fragments of literary language, designed to reflect the specialized knowledge.

In most textbooks authors note that the object of study of the discipline "Ukrainian language for professional purposes" are language rules - the rules of oral and written communication in the professional interaction of speakers. Of course, the basis of language activity is the general language norms that are obligatory for all native speakers of literary language, which expand in the field of culture of professional everyday life ${ }^{22}$ specialized language forms, expressions, signs, as well as gestural means of communication; genre and style priorities of a profession.

The main purpose of training courses, trainings on the formation of communicative competencies in a particular professional field of activity is the deepening and expansion of language knowledge, skills and abilities that are necessary for further application in a particular activity. Therefore, "professional language" as a course has a theoretical and practical focus on developing sustainable skills to build accurate, logical, meaningful, appropriate, expressive, rich, pure professional expression in both oral and written forms. The teacher's goal is not to study the norms of modern Ukrainian literary language by structural-level features, properties, etc., but to teach Ukrainian-language oral and written professional practice taking into account socio-cultural (genre-style) markers of communication in a specialized environment. Language is one of the important components of the professionalism of communicators, their personal traits.

The phenomenon of "professional language" ("language of the profession") is a generalized model of the Ukrainian literary language in the culture of everyday life, which is segmented by the spheres of activity of a particular society.

Respectively, according to the known manuals on professional communication, we observe the similarity of the structure of the course, in which we can distinguish between general and special, as well as narrow special parts.

The common part of the course of teaching the Ukrainian professional language involves the updating of knowledge about the social nature of the language and its social functions, the psychological attitude of students to

22 Бибик С.П. Усна літературна мова в українській культурі повсякдення. Ніжин, 2013. 589 c. 
master the state language. During several classes the idea of: language, its functions, structure of language activity is specified and expanded; the role of literary language in society, its features, forms; status of the state language; differentiated by styles and purpose of modern sources of literary language.

The special part of the course provides deepening of knowledge about the stylistic system of the Ukrainian literary language, in particular its book varieties (official-business, scientific, partly - journalistic), about textual forms of language. Knowledge of the genre and style diversity of official business style is only the beginning of delving into the culture of professional everyday life, motivating to master the book norms of the Ukrainian literary language, the ability to read and compose scientific statements according to the standards of a modern field of knowledge.

It is important to focus in this educational segment on the presentation of the basics of language culture in its broadest sense. It is a question of transfer and knowledge of norms of various structural levels of language, and of work on consolidation of the corresponding competences in practice. And also about knowledge from a profile: about experts in the corresponding branch, history of branch in the country, the world, in region, the city, etc. with application of various information, the widest range of sources (periodical state and specialized professional magazines, newspapers - printed, electronic; modern and archival sources; official-business written and oral, etc.). ${ }^{23}$

Effective differentiation of educational material according to level norms lexical, phraseological, morphological, syntactic, word-forming, stylistic. Their features are constantly in the field of attention of both teachers and students. The polishing of language culture is correlated with the textual approach in teaching. Therefore, the basic are the functional functional varieties of language - scientific (scientific and technical, scientific and natural, scientific and humanitarian); business; scientific and journalistic.

The narrowly focused part of the Ukrainian language course in the professional field is a system of tasks and classes for the formation of communicative competencies of specialists. It is necessary to remind that from the lingoucultural point of view, professional language combines global and national-cultural components. These features are most pronounced at the lexical (lexical-semantic) level: if the terms of the corresponding industry, intersectoral terminological units are common to majority of European literary languages, then professionalism, professional jargon are the representatives of a specific national professional culture. Training at a highly specialized level reveals two main functions of professional language: 1) the function of denoting narrowly professional

23 Єрмоленко С.Я. Професійна мова VS літературний стандарт. Одеський лінгвістичний вісник: науково-практичний журнал: спеціальний випуск. Одеса. 2015. C. $5-11$. 
special concepts and systems of concepts (objects, signs, actions, processes); 2 ) the function of naming well-known concepts, which gives them increased expressiveness, expressiveness, emotionality. ${ }^{24}$ Thus, there can be no question of any special subsystem of national language practice.

Forming the professional language competence, the teacher is focused on deepening into skills that have already been acquired, on expanding the basic vocabulary of a professional speaker, on developing the habit of relying on stereotypical professional clichés, communications. Professional languages are heterogeneous, have different models, for example, the professional language of technology is the language of science (the language of theory, it is a systematized special terminology), it is the language of production (shop language, professional spoken language, as well as production language specialized in small industries), it is the language of advertising of technological processes and production processes, goods. Thus, the highly specialized component also has its own paradigmatic structure and functional breadth: from elitist to everyday; it depends on the level of sociocultural content of speakers (their linguistic and psychological, educational and cultural portrait).

Taking into account the classes on the formation of professional competence of lawyers, among the highly specialized language and cultural skills should:

- find out the essence and functions of the language of law, be worked out the current legislation on the functioning and development of languages in Ukraine (the concept of "state language", "language of a national minority", "language of international communication", "language of justice", etc.);

- form an idea of stylistic and genre varieties of oral and written communication in the legal field; general idea about graphic design of texts of normative-legal acts, about international and national standards of document circulation;

- highlight the features of the functioning of language norms in legal texts;

- deeping into the specification of a legal activity master the basic concepts of legal terminology, namely: pronunciation requirements, use of legal terms in the appropriate meaning and context, with observance of system-semantic relations between them in the legal terminology;

- teach future specialists to use sources of legal terminology dictionaries, reference books, thesauri, encyclopedias;

- form a lasting interest in expanding the culturological content of certain syncretic genre varieties of legal texts (in the field of legal

24 Литовченко I. Динамічні процеси у військовій лексиці української мови (назви зброї, амуніції, споруд). Кривий Ріг : Вид. Р.А. Козлов, 2016. С. 17. 
journalism, lawyer-prosecutor oral official practice), improving the general professional erudition and language culture of a lawyer;

- develop skills of professional (official) etiquette, language and nonlanguage, creating with the help of language means a psychologically positive communicative environment, which would take into account the gender specifics of speakers. ${ }^{25}$

It is important to apply project methods at the narrowly focused part of the Ukrainian language course in the professional field to strengthen the personality-oriented direction of teaching professional language competence. Among them are targeted speeches on a certain list of topics. For example, in the field of law: 1. Dialogue and its organization 2. Functions of the speaker and their implementation during a public speech 3. Components of a public speech 4. How to prepare a public speech 5. Commandments of the speaker 6 . The art of argumentation 7. The ability to listen. ${ }^{26}$ Preparation and presentation of abstracts, in particular on the following issues -1 . The logical component of public speaking. 2. The method of "brainstorming". 3. Optimal ways to prepare a public speech. 4. Judicial speech. 5. History of domestic eloquence. 6 . The concept of the portrait of the audience: signs, types. ${ }^{27}$ And also - summarizing, presentations of this or that subject with use of multimedia means.

Thus, the student "glues" his knowledge and skills in the field of oral and written communication in a particular field of everyday culture, learns to navigate in general and interdisciplinary, narrowly specialized terminology, genre and style varieties of official business communication, if necessary acquires editorial / translation skills while working with professional text, which forms / expands his horizons. In this case, language (systematized knowledge of the norms and rules of literary language, which are used to construct, expressions, texts) and communicative (system of knowledge, skills and abilities to translate globalized and nationally oriented professional information, interaction with colleagues to solve theoretical and practical issues) professional competencies are superimposed and mutually reinforced.

Professional language and cognitive linguistics. From the point of view of cognitive linguistics, language consciousness is segmented - it is divided into sections that are formed in specific everyday practices and codes by which the speaker "switches" in his daily activities depending on the communicative and pragmatic tasks of the situation. The task of cognitive science is to "identify the processes and results of mental activity in real

${ }^{25}$ Мамич М.В. Українська мова за професійним спрямуванням : навчальнометодичний посібник. Одеса : Фенікс. 2020. 163 с.

26 Ялова О.В. Вивчення у вищих навчальних закладах України філософськоукраїнознавчих дисциплін. Філософські та методологічні проблеми права. 2015. № 1-2 (9-10). С. 130-140.

${ }^{27}$ The same. 
conditions" in order to establish ways to categorize the world in consciousness, "description of real processes of cognition and evaluation, conceptual structures that emerge as a reflection of the real world in human consciousness". ${ }^{28}$ The formation of cognitions is associated with the adaptive properties of human mental activity and the formation of "habits", including language: "I include these codes in such an environment." Thus, "special purpose language" is a psycholinguistic phenomenon that can be studied (and planned in class with students) in historical and linguisticdidactic terms. The activity of certain cognitions in the practical or theoretical activities of a person is one of the objects of cognitive linguistics. Related to the latter is the modular concept, according to which human intelligence is a complex of different abilities, each of which can be represented as an independent module, a subsystem with certain structural and functional characteristics. These modules are separated from each other in the human brain.

As a historical phenomenon, these linguistic and cultural modules are modified and passed from generation to generation of professionals through educational activities, communication in small groups. In modern globalization conditions of communication, we observe the growth of internationalization of lexical-phraseological, lexical-word-forming components of "special purpose language". ${ }^{29}$

As one of the perspective directions of development of the theory of professional language, we consider the orientation on anthropocentric aspect: the speaker as the expert in a certain field of activity, the professional language personality (in linguistics such works have already been used). This would contribute to the formation of exemplary models of professional language communication in a particular area of human activity.

\section{CONCLUSIONS}

The subject "Ukrainian language for professional purposes" has a history of its formation, which is closely related to the formation of a structurallevel approach in linguistics, the development of linguistic stylistics and Ukrainian disciplines.

Rapid changes in the educational space are an incentive to rethink the principles of teaching the Ukrainian language in a professional direction. First of all, depending on the specialty, students can be offered historical, psycholinguistic, anthropocentric, personological, text-centric areas of special language teaching. Among the partial methods it is necessary to

${ }^{28}$ Никитин М.В. Основания когнитивной семантики: Учебное пособие. СПб. : Изд-во РГПУ им. А.И. Герцена, 2003. С. 5.

29 Schwarz M. Kognitive Semantiktheorie und neuropsychologische Realitaet: Repraesentationale und prozedurale Aspekte der semantischen Kompetenz. Tuebingen, 1992. C. $13-14$. 
develop a method of project-based learning, which encourages individual indepth study of a material.

\section{SUMMARY}

This section of the collective monograph offers a generalized overview of linguistic research of professional language in Ukraine. Attention to this theoretical and practical direction is due to a significant expansion of the spheres of functioning of the Ukrainian language, primarily - the introduction of the Ukrainian literary language in specialized education.

The article comprehends the issues of the history of studying the professional language in Ukraine, the theoretical preconditions for the separation of the special purpose language, the problems of research in the relevant segment of knowledge about the Ukrainian literary language.

It is concluded that changes in the educational space are an incentive to review, modernize the principles of teaching the Ukrainian language in a professional direction. Historical, psycholinguistic, anthropocentric, personological, text-centric areas of special-purpose language teaching should be used in the educational environment. Among the partial methods it is necessary to develop a method of project-based learning, which encourages individual in-depth study of a material. It is time to create highly specialized dictionaries.

\section{1. Лисиченко Т.Ю. Леонід Арсенійович Булаховський} (до 125-річчя від дня народження). Лінгвістичні дослідження. 2013. Вип. 35. С. 277.

2. Черемська О.С. Становлення і розвиток Харківської філологічної школи (XIX - перша третина XX ст.). Харків, 2020. С. 110.

3. Червінська Л.Ф., Дикий А.Т. Покажчик української мови : матеріали по 1929 р. Харків, 1929 (1930). 287 с.

4. Закономірності розвитку українського усного літературного мовлення / [Баранник Д.Х., Білодід І. К., Близниченко Л.А. та ін.] ; за ред. І.К. Білодіда. Київ, 1965. с. 305.

5. Словарь славянской лингвистической терминологии; под ред. А. Эдлички. Прага, 1977.

6. Сучасна українська літературна мова : стилістика ; за ред. І.К. Білодіда. Київ, 1973. С. 88.

7. Курс сучасної української літературної мови ; за ред. Л.А. Булаховського. Київ, 1951. Т. 1. С. 41

8. Жовтобрюх М.А., Кулик Б.М. Курс сучасної української літературної мови : [у 2 ч.]. Київ, 1965. Ч. 1. С. 72

9. Ващенко В.С. Українська лексикологія: семантико-стилістична типологія слів. Дніпропетровськ, 1979. С. 92-93. 
10. Михайлова Т.В. Семантичні відношення в українській науковотехнічній термінології. Харків, 2001. С. 44-45; Пристайко Т.С. Лексико-номинативная организация специального текста. Дніпропетровськ. 1996. С. 50; Винник В.О. Професіоналізм. Українська мова. Енциклопедія. Київ, 2004. С. 500.

11. Голованова Е.И. Введение в когнитивное терминоведение. Москва, 2011. с. 56.

12. Канделаки Т.Л. Значение терминов и системы значений научнотехнических терминологий. Проблемы языка науки и техники: логичиские, лингвистичиские и историко-научные аспекты терминологии. Москва, 1970. 232 с.

13. Тихоненко О.В. Становлення норм офіційно-ділового стилю української мови у 20-30-ті pp. XX ст. : автореф. дис. ... канд. філол. наук. Харків, 2011. С. 125.

14. Мамич М.В. Ділова українська мова в публічному управлінні : навчальний посібник. Одеса. 2020. 68 с.

15. Раздуев А.В. Современный английский подъязык нанотехнологий: структурно-семантическая, когнитивно-фреймовая и лексикографическая модели : дис. ... кандидата филологических наук. Пятигорск, 2013. С. 39.

16. Лейчик В.М. Языки для специальных целей - функциональные разновидности современных развитых национальных языков. Общие $u$ частные проблемы функииональных целей. Москва, 1986. С. 28-43.

17. Забросаева И.А., Конурбаев М. Э. От LSP до специализированного дискурса: исторический срез. Язык, сознание, коммуникация: Сб. статей ; ред. В.В. Красных, А.И. Изотов. М. 2014. Вып. 49.

18. Хомутова Т.Н. Язык для специальных целей (LSP): лингвистический аспект. Вестник ЮУрГУ. 2007. № 16. С. 70.

19.Бибик С.П. Усна літературна мова в українській культурі повсякдення. Ніжин, 2013. 589 с.

20. Єрмоленко С.Я. Професійна мова VS літературний стандарт. Одеський лінгвістичний вісник: науково-практичний журнал: спеціальний випуск. Одеса. 2015. С. 5-11.

21. Литовченко I. Динамічні процеси у військовій лексиці української мови (назви зброї, амуніції, споруд). Кривий Ріг, 2016. C. 17.

22. Мамич М.В. Українська мова за професійним спрямуванням : навчально-методичний посібник. Одеса, 2020. 163 с.

23. Ялова О.В. Вивчення у вищих навчальних закладах України філософсько-українознавчих дисциплін. Філософські та методологічні проблеми права. 2015. № 1-2 (9-10). С. 130-140.

24. Никитин М.В. Основания когнитивной семантики: Учебное пособие. СПб. : Изд-во РГПУ им. А.И. Герцена, 2003. С. 5. 
25. Schwarz M. Kognitive Semantiktheorie und neuropsychologische Realitaet: Repraesentationale und prozedurale Aspekte der semantischen Kompetenz. Tuebingen, 1992. C. 13-14.

Information about the authors: Mamich M. V., Doctor of Philological Sciences, Professor, Head of the Department of Applied Linguistics National University "Odesa Law Academy" 23, Fontanska doroha, str., Odesa, 65009, Ukraine

Shevchenko-Bitenska O. V., Candidate of Law, Associate Professor, Associate Professor at the Department of Foreign Languages № 1 National University "Odesa Law Academy" 23, Fontanska doroha, str., Odesa, 65009, Ukraine 